\title{
Subfossil Chironomidae and other palaeoecological proxies in the reconstruction of the Late Vistulian environmental history in central Poland: case study of oxbow fill in Luciąża River valley
}

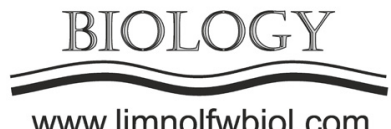

www.limnolfwbiol.com

\author{
Antczak-Orlewska O. ${ }^{1,2}$, Płóciennik M. ${ }^{2}$, Okupny D. ${ }^{3}$, Pawłowski D. ${ }^{4}$, \\ Stachowicz-Rybka R. ${ }^{5}$, Szmańda J. ${ }^{6}$, Wacnik A. ${ }^{5}$, Krąpiec M. ${ }^{7}$, Kotrys B. ${ }^{8}$, \\ Luoto T.P. ${ }^{9}$, Smith D. ${ }^{10}$, Kittel P. ${ }^{11}$ \\ ${ }^{1}$ University of Gdansk, Laboratory of Palaeoecology and Archaeobotany, Department of Plant Ecology, Faculty of Biology, Gdansk, \\ Poland \\ ${ }^{2}$ University of Lodz, Department of Invertebrate Zoology and Hydrobiology, Lodz, Poland \\ ${ }^{3}$ University of Szczecin, Institute of Marine and Environmental Sciences, Szczecin, Poland \\ ${ }^{4}$ University of Adam Mickiewicz, Institute of Geology, Poznan, Poland \\ ${ }^{5}$ W. Szafer Institute of Botany, Polish Academy of Sciences, Krakow, Poland \\ ${ }^{6}$ Institute of Geography, Pedagogical University of Krakow, Krakow, Poland \\ ${ }^{7}$ Faculty of Geology, Geophysics and Environmental Protection, AGH - University of Science and Technology, Krakow, Poland \\ ${ }^{8}$ Polish Geological Institute-National Research Institute, Szczecin, Poland \\ ${ }^{9}$ Department of Geosciences and Geography, University of Helsinki, Helsinki, Finland \\ ${ }^{10}$ Department of Classics, Ancient History and Archaeology, University of Birmingham, Birmingham, UK \\ ${ }^{11}$ University of Lodz, Faculty of Geographical Sciences, Department of Geomorphology and Palaeogeography, Lodz, Poland
}

\begin{abstract}
The fast sedimentation rate of Rozprza palaeo-oxbow deposits gives a chance for tracking environmental changes in the end of the Late Vistulian very thoroughly. The range of palaeoecological analyses were done, resulting in reconstructions of vegetation history, climate and habitat changes. The chironomid-inferred summer temperatures indicate the short cooling in the late Allerød, confirmed by the plant macrofossils. It may correspond to 'Gerzensee oscillation', recorded mainly from western Europe. The studied oxbow was a truly aquatic ecosystem until the end of Younger Dryas, with diverse invertebrate fauna. The second phase of the oxbow-lake was characterised by its systematic overgrowing and, finally, mire development with overbank deposition in the Holocene. The wide range of used proxies provided a reliable picture of the Late Glacial oxbow evolution in Central Poland.
\end{abstract}

Keywords: climate, Late Glacial, palaeoecology, palaeolimnology, multi-proxy study

\section{Introduction and methods}

Multi-proxy studies are getting recently more and more attention, as they are the most comprehensive way to achieve a reliable, holistic reconstruction of the past environments. Plant macrofossils serve as good indicators of local habitat character, while pollen is useful to reflect the environment in the regional scale. However, vegetation often respond with some delay to a rapid and short-term climate changes, while Chironomidae (Diptera) are sensitive to even minor, local signals. They are ubiquitous and ecologically diverse, so they play a vital role in palaeoenvironmental reconstructions. Midges are useful mostly in the truly aquatic conditions, whether other insects, mainly beetles (Coleoptera), are a good environmental indicators also in peatlands. Cladocera are good indicators of local hydrological conditions.

Our study at Rozprza (51 $18^{\circ} 07^{\prime \prime} \mathrm{N}$; $19^{\circ} 40^{\prime} 04^{\prime \prime} \mathrm{E}$; $183 \mathrm{~m}$ a.s.l.) was conducted as a part of archaeological and palaeoenvironmental investigations of the Medieval ringfort remnants (Kittel et al., 2018a,b; Sikora et al., 2019). The site is located in Central Poland, in the Luciąża River valley floor (the 3rdorder river in the Vistula River Basin). In order to choose proper sampling sites in the field, not only was topography and geomorphology of studied area 
thoroughly mapped, but also the combination of other non-destructive methods along with geological hand augering was used (Sikora et al., 2015, Kittel et al., 2018a). The results of geophysical prospections and later the geological survey confirmed the existence of a large-size palaeochannel filled with organic (gyttja and peat) and partially inorganic deposits (sands and silts with organic mud) (Kittel et al., 2018a). In order to recognise the palaeochannel fill and overbank alluvium cover, the trench $(2 \times 10 \mathrm{~m})$ was excavated. The core of organic deposits for palaeoecological analyses was collected as monoliths into metal boxes, as to preserve the undisturbed structure of the sediments, and dated with the radiocarbon $\left({ }^{14} \mathrm{C}\right)$ method. Two selected samples of bulk of organic deposits were dated using the liquid scintillation technique (LST) and three samples of selected terrestrial plant macrofossils - using accelerator mass spectrometry (AMS).

The samples for pollen and Cladocera analyses were taken at $2 \mathrm{~cm}$ intervals in $1 \mathrm{~cm}$ slices, whereas for sedimentological, geochemical, plant macrofossils, Chironomidae and other insect analyses - as contiguous $2 \mathrm{~cm}$ slices. The laboratory procedures followed standard techniques. The chironomid-inferred mean July air temperature was reconstructed using EastEuropean and Swiss-Norwegian-Polish Training Sets, with the application of WA-PLS and Artificial Neural Network (ANN) methods.

\section{Results and conclusions}

The aquatic invertebrates (Chironomidae and Cladocera) in the oxbow lake underwent significant fluctuations, delineating the periods of local and regional palaeoenvironmental changes. After the favourable conditions in the Allerød and Younger Dryas, their number suddenly dropped in the Holocene. For this reason, the climate reconstructions were focused on the Late Glacial part of the sequence $(214-180 \mathrm{~cm}$ b.g.1.). Both invertebrate assemblages were dominated by macrophyte/sediment-associated taxa. Among chironomids the highest share represented collectors, followed by grazers. They were largely associated with a clastic matter. In turn, within Cladocera assemblages dominated taxa known to occur over a wide range of conditions, and they are tolerant of environmental stress, including cold climate.

The Chironomidae-inferred quantitative reconstructions reveal low mean summer temperatures in the late Allerød (up to $11.9^{\circ} \mathrm{C}$ ), which can be referred to the 'Gerzensee oscillation' (ca. 13,200-12,900 BP), so far recorded mainly from western Europe. The cool conditions are confirmed by the plant macrofossils record (mainly Betula nana and Arctostaphylos uva-ursi). In the end of the Younger Dryas the oxbow started to paludify, the aquatic invertebrates and plants were replaced by the telmatic taxa. According to the pollen stratigraphy, the oxbow surroundings were constituted mainly by pine and birch forests.

The results of our multi-proxy palaeoecological study on the Luciąża River palaeo-oxbow fill at Rozprza are essential for further research on palaeoenvironmental changes in the Late Glacial, and particularly in the Late Allerød, in Central Europe.

\section{Acknowledgements}

The research project has been financed by grants from The Polish National Science Centre based on the decision No. "DEC-2013/11/B/HS3/03785".

\section{References}

Kittel P., Sikora J., Wroniecki P. 2018a. A Late Medieval motte-and-bailey settlement in a lowland river valley landscape of central Poland. Geoarchaeology 33(5): 558-578.

Kittel P., Sikora J., Antczak O. et al. 2018b. The palaeoecological development of the Late Medieval moat Multiproxy research at Rozprza, Central Poland. Quaternary International 482: 131-156.

Sikora J., Kittel P., Wroniecki P. 2015. From a point on the map to a shape in the landscape. Non-invasive verification of medieval ring-forts in Central Poland: Rozprza case study. Archaeologia Polona 53: 510-514.

Sikora J., Kittel P., Frączek M. et al. 2019. A palaeoenvironmental reconstruction of the rampart construction of the medieval ring-fort in Rozprza, Central Poland. Archaeological and Anthropological Sciences 11(8): 4187-4219. 